\title{
Girdling, maturation degree and ethephon on azalea cuttings establishment
} \author{
Larissa Leandro Pires ${ }^{2}$ (1) \\ ${ }^{1}$ Universidade Estadual do Mato Grosso do Sul, Dourados-MS, Brazil. \\ ${ }^{2}$ Universidade Federal de Goiás, Goiânia-GO, Brazil. \\ ${ }^{3}$ Universidade Federal do Triângulo Mineiro, Uberaba-MG, Brazil.
}

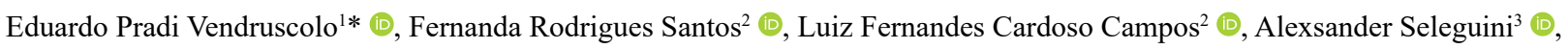

\begin{abstract}
The sector that ranges from cultivation to sale of ornamental species is highlighted in the agribusiness scenario, due to the frequent increase in demand for its products. This importance encourages the exploration of new technologies that allow the development of protocols for the multiplication of species of commercial interest. Thus, the objective of this study was to evaluate and validate the use of girdling, ethephon and the selection of degree of branch maturation as techniques for increasing the establishment of cuttings of Rhododendron simsii Planch. The treatments combining the three study factors were applied to the branches of the parent plants: two levels of girdling (with and without), two levels of application of ethephon at the concentration of $900 \mathrm{mg} \mathrm{L}^{-1}$ (with and without application) and two degrees of maturation (woody and herbaceous). It was found that the presence of branch girdling increased the rate of establishment of cuttings by $43.75 \%$, while the joint use of two techniques, the application of ethephon and the selection of herbaceous cuttings, resulted in an establishment rate $56.25 \%$ higher than the average of other treatments. Thus, it can be concluded that both branch girdling and the application of ethephon combined with the use of herbaceous branches can be used as techniques for the greater establishment of cuttings of Rhododendron simsii Planch.
\end{abstract}

Keywords: azalea; ornamental species; vegetative propagation; phytohormones; ethylene.

\section{Resumo}

Anelamento, grau de maturação e ethephon no estabelecimento de estacas de azaleia

O setor que abrange desde o cultivo até a comercialização de espécies ornamentais é destaque no cenário do agronegócio, devido ao frequente aumento da demanda pelos seus produtos.Essa importância incentiva a busca por novas tecnologias que permitam o desenvolvimento de protocolos para a multiplicação de espécies de interesse comercial. Assim, o objetivo deste estudo foi avaliar e validar a utilização do anelamento, do ethephon e da seleção do grau de maturação de ramos como técnicas para o incremento do estabelecimento de estacas de Rhododendron simsii Planch.Os tratamentos foram aplicados aos ramos das plantas matrizes, combinandose os três fatores de estudos, sendo dois níveis de anelamento (com e sem), dois níveis de aplicação de ethephon na concentração de $900 \mathrm{mg} \mathrm{L}^{-1}$ (com e sem aplicação) e dois graus de maturação (lenhoso e herbáceo). Verificou-se que a presença de anelamento dos ramos incrementou a taxa de estabelecimento das estacas em $43,75 \%$, enquanto a utilização conjunta de duas técnicas, a aplicação de ethephon e a seleção de estacas herbáceas na azaleia, resultou em uma taxa de estabelecimento 56,25\% maior que a média dos demais tratamentos. Dessa maneira, pode-se concluir que tanto o anelamento de ramos quanto a aplicação de ethephon, combinada à utilização de ramos herbáceos, podem ser utilizados como técnicas para o maior estabelecimento de estacas de Rhododendron simsii Planch.

Palavras-chave: azaleia; espécie ornamental; propagação vegetativa; fitormônios; etileno.

\section{INTRODUCTION}

Azalea (Rhododendron simsii Planch.) is an ornamental plant in the Ericaceae family, originating in Asia (Shrestha et al., 2018) and widely cultivated in Brazil (Bezerra et al., 2020). In landscaping, this shrub is commonly used in pots, as well as in gardens, as an isolated plant or as the constituting elements of borders, rows and massifs. Its ornamental value owes to the beauty of its colorful flowers, ranging from white to red, purplish or pinkish, which can be simple or folded and appear in the autumn-winter period (Lorenzi, 2015; Feliciana et al., 2017; Mo et al., 2020).

*Corresponding author: agrovendruscolo@gmail.com 
The propagation of azalea can be sexual or, more commonly, asexual, because of the genetic heterogeneity observed in the seeds (Zaytseva and Novikova, 2018). Traditionally, stem cuttings are used to propagate most Rhododendron species (Eeckhaut et al., 2009). However, its rooting is often difficult, with a small percentage of catching and, consequently, low seedling production (Lone et al., 2010; Li et al., 2017).

The use of cuttings is an important technique applied to the production of seedlings of species of economic interest, such as ornamental, forest and fruit. This method yields plants of high quality, in addition to the multiplication, through cloning, of vegetables with high productive potential or other characteristics demanded by producers and consumers (Georget et al., 2017; Vendruscolo et al., 2017; Wetzstein et al., 2018).

Success of cuttings use will depend on factors intrinsic to the species, as well as external factors that act on the morphophysiological conditions of the mother plants. These conditions may be due to natural changes in the environment, but they can also be caused on purpose by human action, in order to obtain better results. The treatment of parent plants with hormonal and nutritional products has been studied with the objective of increasing rooting levels and the consequent quality of seedlings (Véras et al., 2017; Villanova et al., 2017; Hilgert et al., 2020).

Other established and widely used techniques in the production of vegetable plant seedlings are girdling and selection of the degree of maturation of cuttings. In girdling, the accumulation of photoassimilates and phytohormones in the branch, resulting from the presence of the Malpighi ring, favors the development of roots in the cuttings and, consequently, their establishment. The degree of maturation of the branches can also influence the survival and the emission of new structures; however, this degree will vary according to the species and its characteristics (Lucena et al., 2014; Stuepp et al., 2016; Ferus et al., 2017).

Contrary to the aforementioned techniques, the use of ethephon (2-chloroethyl) phosphonic acid, a synthetic product that precedes ethylene, is contradictory in the asexual production of seedlings. In cutting, ethylene is synthesized when auxins are applied, stimulating the formation and development of roots, thus increasing the percentage of cuttings rooting (Fachinello et al., 2005).

In viticulture, ethephon applied to mother plants prior to cutting collection stimulates rooting, in addition to controlling several other physiological processes related to cellular elongation, enzymatic activity and nutritional status (Szyjewicz et al., 1984; Petri et al., 2016). Some studies point to a positive effect of the application of this compound on the emission characteristics of new shoots and their development (Abreu et al., 2017). This effect is the result of the accumulation of nutrients and reserves, resulting from the induced senescence of the leaves, and its consequent translocation to the buds (Fracaro and Boliani, 2001).

Better results in rooting cuttings of guava (Psidium guajava L.) (Marco et al., 1998) and plum (Prunus salicina Lindl.) were observed using ethephon (Dutra et al., 1997). Negi et al. (2010) found a positive influence of ethylene in the formation of adventitious roots in tomato seedlings (Solanum lycopersicum L.), using 1-aminocyclopropane carboxylic acid (ACC) as a precursor of ethylene.

There are no studies on the use of ethephon and girdling in the treatment of azalea mother plants, although the results have been verified for some horticultural species, mainly woody fruit. In this way, the hypothesis arises that these techniques can be applied to floriculture.

Therefore, it appears that the isolated use of techniques to increase success in the formation of seedlings by cutting is frequently studied. However, we lack information about the joint use of these techniques, which can bring better results. Thus, the objective of this study was to evaluate and validate the use of girdling, ethephon and the selection of degree of branch maturation as techniques for increasing the establishment of cuttings of Rhododendron simsii Planch.

\section{MATERIAL AND METHODS}

The branches used for the study were collected from azalea plants located at the School of Agronomy of the Federal University of Goiás, in the city of Goiânia, located in the central region of the state of Goiás, with geographical coordinates of $16^{\circ} 40^{\prime} \mathrm{S}$ and $49^{\circ} 15^{\prime} \mathrm{W}$, and an altitude of $750 \mathrm{~m}$.

The test was carried out in a randomized block design in a $2 \times 2 \times 2$ factorial scheme, totaling eight treatments. The treatments combining the three study factors were applied to the branches of the parent plants: two levels of girdling (with and without), two levels of ethephon (with and without application) and two levels of branch maturation (woody and herbaceous). The treatments were applied to five branches, about $1.20 \mathrm{~m}$ long. Each experimental unit was composed of five cuttings.

Girdling was executed at the base of the branch, close to the neck, using a pocket knife, on March 27, 2017, seven days before the cuttings were removed, and consisted of the total elimination of a bark ring approximately $1 \mathrm{~cm}$ wide and $1 \mathrm{~mm}$ deep. The idea was to break the phloem without damaging the xylem.

Ethephon (2-chloroethyl) phosphonic acid (Ethrel ${ }^{\circledR}$ ) was applied to the respective branches after girdling, by spraying asolution of $900 \mathrm{mg} \mathrm{L}^{-1}$ of the active ingredient, common for vine defoliation in the region, reaching all branch leaves and using a manual sprayer with a flow of $10 \mathrm{~mL} \mathrm{~s}^{-1}$. Seven days after application, when there was a total fall of leaves applied with ethephon, the branches were cut and divided into cuttings $10 \mathrm{~cm}$ long (Feliciana et al., 2017). These cuttings were separated into herbaceous or woody, by observing the absence and presence of dark colored lignified cortex, respectively.

The cuttings were planted in plastic trays with a capacity of $500 \mathrm{~mL}$, filled with commercial peat substrate $\left(\right.$ Plantmax $\left.^{\circledR}\right)$, previously moistened, burying half the stake. Optimal conditions for the growth of Rhododendron species range from $18-25^{\circ} \mathrm{C}$ and high air humidity (Li et al., 2020), so the whole plant was taken to the germination chamber with a temperature of $25 \pm 1{ }^{\circ} \mathrm{C}$, relative humidity of $90 \%$ and a photoperiod of $12 \mathrm{~h}$, for 25 days, without the need to replace the water in the substrate. After this period, the cuttings were removed from the substrate and visually 
evaluated for their establishment, verified when there was joint emission of aerial structures (shoots) and roots.

The data was submitted to analysis of variance and compared by least significant difference (LSD) test, with a probability of $5 \%$.

\section{RESULTS AND DISCUSSION}

No interaction was observed between the joint use of girdling,ethefon and the degree of maturation of the cuttings. However, branch girdling had an isolated effect, and there was an interaction between ethephon application and the maturation of the cuttings on the establishment index (Table 1).

It was found that the presence of branch girdling increased the establishment of azalea cuttings by $43.75 \%$ (Figure 1), characterized by the joint development of root structures and shoots. Branch girdlingacts to interrupt the translocation of sap by the phloem, preventing the downward movement of photoassimilates and nutrients towards the plant's root system. This temporarily provides the accumulation of carbohydrates and hormones in the aerial portion of the vegetable (Mehouachi et al., 2009).

Fachinello et al. (1988), working with apple rootstock matrices "Malling-Merton 1061", concluded that the girdling also

Table 1. Probabilities of the effects of girdling, maturation of the cuttings, and ethephon application on establishment index of cuttings.

\begin{tabular}{|c|c|}
\hline Factor & Establishment index \\
\hline Girdling & $* * *$ \\
\hline Maturation & $*$ \\
\hline Ethephon & $* *$ \\
\hline Girdling $\times$ Maturation & $\mathrm{ns}$ \\
\hline Girdling $\times$ Ethephon & $\mathrm{ns}$ \\
\hline Maturation $\times$ Ethephon & $*$ \\
\hline Girdling $\times$ Maturation $\times$ Ethephon & $\mathrm{ns}$ \\
\hline $\mathrm{CV} \%$ & 34.62 \\
\hline
\end{tabular}

${ }^{*} \mathrm{p}<0.05 ;{ }^{* *} \mathrm{p}<0.01 ; * * * \mathrm{p}<0.001 ;$ ns: no significant differences; $\times$ : interaction; $\mathrm{CV}$ : coeficient of variation.

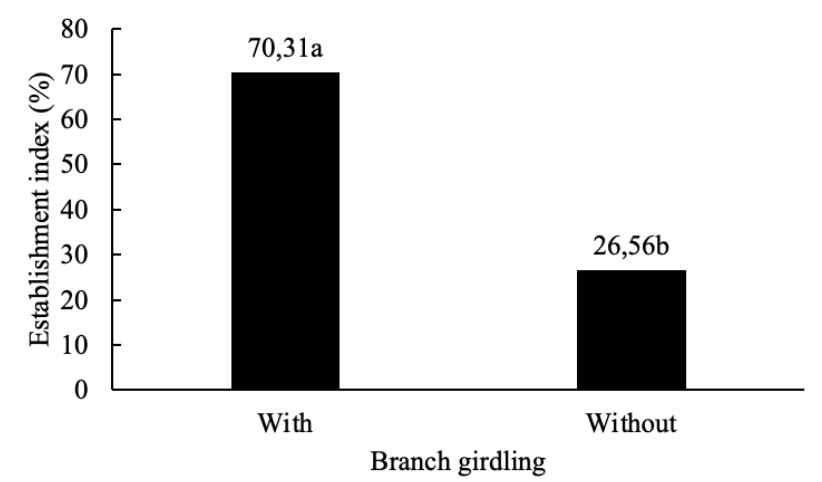

Figure 1. Establishment of azalea cuttings (Rhododendron simsii Planch) from branches with or without girdling. $*$ Different letters differ from each other by the LSD test at $5 \%$ probability. stimulated the rooting of the cuttings. The authors found a greater accumulation of total soluble sugars in these branches, which is the only source of carbohydrates that can provide energy for the formation and development of roots.In addition to providing a greater accumulation of starch and sugars, girdlingallowed the addition of rooting cofactors such as phenolic compounds and polyamines in olive cuttings, increasing the rooting potential of this species (Denaxa et al., 2021).

The combined use of two techniques- the application of ethephon and the selection of herbaceous cuttings in azalea- resulted in an establishment rate $56.25 \%$ higher than the average of the other treatments (Figure 2). Similar results have been reported by Dhua et al. (1982), applying ethephon to guava branches (Psidium guajava L.), collecting herbaceous cuttings (from the ends of the branches) after seven days, treating or not treating plants with indolbutyric acid (IBA). The authors found that rooting was around $100 \%$ better in cuttings that received treatment with ethephon and, later, with IBA. Véras et al. (2018) also observed an increase in the percentage of rooting and the number of roots on umbuzeiro cuttings (Spondias tuberosa Arruda), when combining ethephon and with AIB. In addition, there are reports that ethylene acts as an important stimulator of adventitious root formation in Petunia hybrida (Hook. Fil.) Vilm by Druege et al. (2014), and in marigold (Tagetes erecta L.) (Jin et al., 2017).

In the propagation of azalea for commercial purposes, according to Chalfun et al. (1997), the best results are obtained with the use of semi-hardwood cuttings, since the woody ones have a higher degree of lignification, making rooting difficult. In addition, the chemical composition of the tissue varies along the branch, causing differences in rooting in cuttings from different parts of it (Santos et al., 2016). Therefore, the higher rate of establishment, in herbaceous cuttings, may be influenced by the levels of phenolic compounds and carbohydrates present in them, due to the translocation of the photoassimilates present in the leaves, at the time of senescence induced in these cuttingswith the use of ethephon.

Considering the results, we infer that the treatments evaluated in this study have the potential to be used for

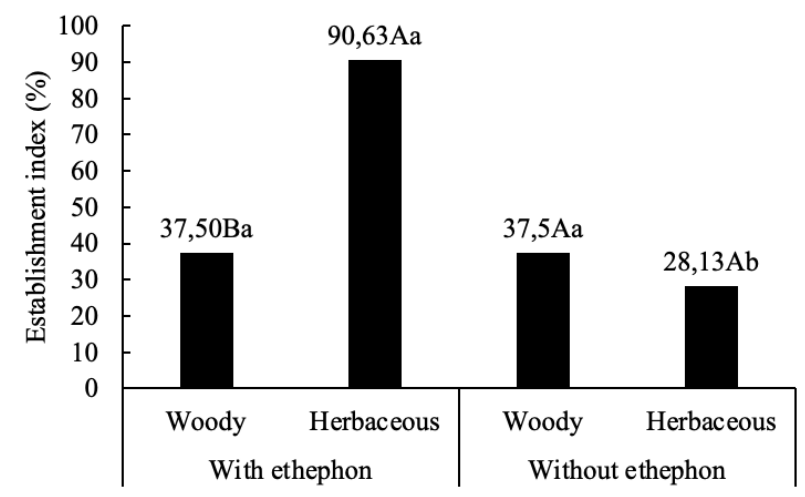

Figure 2. Establishment of azalea cuttings (Rhododendron simsii Planch) of different degrees of maturity, from branches sprayed or not with ethephon. *Different letters, upper case for the degree of maturity and lower case for the presence of ethephon, differ by LSD test at $5 \%$ probability. 
azalea. The advancement of the methodology depends mainly on the establishment of ethephon dosages, suitable for the various ornamental species grown.

\section{CONCLUSION}

Branch girdling and the application of ethephon combined with the use of herbaceous branches can be used as techniques for the greater establishment of azalea cuttings.

\section{AUTHOR CONTRIBUTION}

EPV: project idea, formulation of the aims, research planning; experiment performing, text writing. FRS: collected the data and analysis, text writing and critical review. LFCC: experiment performing, collected the data, text writing and critical review. AS: experiment performing, data analysis and statistics, text writing. LLP: data analysis, text writing and critical review.

\section{ACKNOWLEDGMENTS}

This study was financed in part by the Coordenação de Aperfeiçoamento de Pessoal de Nível Superior - Brasil (CAPES) Finance Code 001

\section{REFERENCES}

ABREU, C.M.; CAMPOS, L.F.C.; ASCHERI, D.P.R.; SELEGUINI, A. Produtividade e qualidade de frutos de videira 'Isabel' em função das doses de etefon e épocas de poda. Revista de Agricultura Neotropical, v.4, n.1, p.1220, 2017. https://doi.org/10.32404/rean.v4i1.1170

BEZERRA, A.K.D.; FERRAZ, M.V.; PIVETTA, K.F.L.; NOGUEIRA, M.R.; MAZZINI-GUEDES, R.B. Rooting of azalea cuttings of Otto and Terra Nova cultivars treated with auxin and boron. Ornamental Horticulture, v.26, n.1, p.77-88, 2020. https://doi.org/10.1590/2447-536x. v26i1.2041

CHALFUN, N.N.J.; HOFFMANN, A.; CHALFUN JR., A.; JESUS, A.M.S. Efeito da auxina e do anelamento no enraizamento de estacas semi-lenhosas de azaleia. Ciência e Agrotecnologia, v.21, n.4, p.516-520, 1997.

DENAXA, N.K.; VEMMOS, S.N.; ROUSSOS, P.A. Shoot girdling improves rooting performance of kalamata olive cuttings by upregulating carbohydrates, polyamines and phenolic compounds. Agriculture, v.11, n.1, p.71-87, 2021. https://doi.org/10.3390/agriculture11010071

DHUA, R.S.; MITRA, S.K.; SEN, S.K.; BOSE, T.K. Effect of ethephon and IBA on rooting of guava. Science and Culture, v.48, n.12, p.444-445, 1982.

DRUEGE, U.; FRANKEN, P.; LISCHEWSKI, S.; AHKAMI, A.H.; ZERCHE, S.; HAUSE, B.; HAJIREZAEI, M.R. Transcriptomic analysis reveals ethylene as stimulator and auxin as regulator of adventitious root formation in petunia cuttings. Frontiers in Plant Science, v.5, n.1, p.494-494, 2014. https://doi.org/10.3389/fpls.2014.00494

DUTRA, L.F.; TONIETTO, A.; KERSTEN, E. Enraizamento de estacas de ameixeira (Prunus salicina Lindl) tratadas com ácido indolbutírico e Ethephon. Revista Brasileira de Agrociência, v.3, n.2, p.59-64, 1997. https:// doi.org/10.18539/cast.v3i2.186

EECKHAUT, T.; JANSSENS, K.; KEYSER, E.; RIEK, J. Micropropagation of Rhododendron. Methods in Molecular Biology, v.589, p.141-152, 2009. https://doi. org/10.1007/978-1-60327-114-1_14

FACHINELLO, J.C.; HOFFMANN, A.; NACHTIGAL, J.C. (Eds.). Propagação de plantas frutíferas. Brasília: Embrapa Informação Tecnológica. Bento Gonçalves: Embrapa Uva e Vinho, 2005. 221 p.

FACHINELLO, J.C.; LUCCHESI, A.A.; GUTIERREZ, L.E. Influência do anelamento na nutrição e no enraizamanto de estacas lenhosas do porta-enxerto 'Malling-Merton 1061'. Pesquisa Agropecuária Brasileira, v.23, n.9, p.1025-1031, 1988.

FELICIANA, A.M.C.; MORAIS, E.G.; REIS, E.S.; CORRÊA, R.M.; GONTIJO, A.S.; VAZ, G.H.B. Influência de auxinas e tamanho de estacas no enraizamento de azaleia (Rhododendron simsii Planch.). Global Science and Technology, Rio Verde, v.10, n.1, p.43-50, 2017.

FERUS, P.; KONÔPKOVÁ, J.; BOŠIAKOVÁ, D.; HOŤKA, P. Effective rhododendron propagation through stem cuttings. Journal of Applied Horticulture, v.19, n.3, p.226-229, 2017.

FRACARO, A.A.; BOLIANI, A.C. Efeito do ethephon em videira 'Rubi' (Vitis vinifera L.), cultivada na região noroeste do Estado de São Paulo. Revista Brasileira de Fruticultura, v.23, n.3, p.510-512, 2001. http://dx.doi. org/10.1590/S0100-29452001000300011

GEORGET,F.; COURTEL, P.; GARCIA, E.M.; HIDALGO, M.; ALPIZAR, E.; BREITLER, J.C.; BERTRAND, B.; ETIENNE, H. Somatic embryogenesis-derived coffee plantlets can be efficiently propagated by horticultural rooted mini-cuttings: a boost for somatic embryogenesis. Scientia Horticulturae, v.216, p.177-185, 2017. https:// doi.org/10.1016/j.scienta.2016.12.017

HILGERT, M.A.; SÁ, L.C.; LAZAROTTO, M.; SOUZA, P.V.D.; MARTINS, C.R. Collection period and indolebutyric acid on the rooting of adult pecan plant cuttings. Pesquisa Agropecuária Brasileira, v.55, e01656, 2020. https://doi. org/10.1590/S1678-3921.pab2020.v55.01656

JIN, X.; LIAO, W.B.; YU, J.H.; REN, P.J.; DAWUDA, M.M.; WANG, M.; NIU, L.J.; LI, X.P.; XU, X.T. Nitric oxide is involved in ethylene-induced adventitious rooting in marigold (Tagetes erecta L.). Canadian Journal of 
Plant Science, v.97, n.4, p.620-631, 2017. https://doi. org/10.1139/cjps-2016-0156

LI, C.; QUAN, W.; CHEN, X. Dynamics of endogenous hormones, anatomical structure during the cutting propagation of wild: Rhododendron sacbrifolium Franch. Pakistan Journal of Botany, v.49, n.6, p.2295-2299, 2017.

LONE, A.B.; UNEMOTO, L.K.; YAMAMOTO, L.Y.; COSTA, L.; SCHNITZER, J.A.; SATO, A.J.; RICCE, W.S.; ASSIS, A.M.; ROBERTO, S.R. Enraizamento de estacas de azaleia (Rhododendron simsii Planch.) no outono em AIB e diferentes substratos. Ciência Rural, v.40, n.8, p.1720-1725, 2010. http://dx.doi.org/10.1590/S0103-84782010000800008

LORENZI, H. Plantas para jardim no Brasil: herbáceas, arbustivas e trepadeiras. 2. ed. Nova Odessa: Instituto Plantarum. 2015. 1120 p.

LUCENA，R.J.; PIMENTA，M.A.C.; ARRIEL， E.F.; LUCENA, R.J.; FREIRE, A.L.O. Níveis de anelamento, AIB e proteção do substrato na clonagem de Cnidoscolus quercifolius por alporquia. Revista Verde de Agroecologia e Desenvolvimento Sustentável, v.9, n.2, p.173-184, 2014

MARCO, C.A.; KERSTEN, E.; SILVA, J.G.C. Influência do ethephon e do ácido indolbutírico no enraizamento de estacas de ramos de goiabeira (Psidium guajava L.). Ciência Rural, v.28, n.2 p.221-224, 1998. http://dx.doi. org/10.1590/S0103-84781998000200006

MEHOUACHI, J.; IGLESIAS, D.J.; AGUSTÍ, M.; TALÓN, M. Delay of early fruitlet abscisión by Branco girdling in Citrus coincides with previous increases in carbohydrate and gibberelin concentrations. Plant Growth Regulator, v.58, n.1, p.15-23, 2009.

MO, L.; CHEN, J.H.; CHEN, F.; XU, Q.-W.; TONG, Z.K.; HUANG, H.-H.; DONG, R.-H.; LOU, X.-Z.; LIN, E.$\mathrm{P}$. Induction and characterization of polyploids from seeds of Rhododendron fortunei Lindl. Journal of Integrative Agriculture, v.19, n.8, p.2016-2026, 2020. https://doi. org/10.1016/S2095-3119(20)63210-5

NEGI, S.; SUKUMAR, P.; LIU, X.; COHEN, J.D.; MUDAY, G.K. Genetic dissection of the role of ethylene in regulating auxin-dependent lateral and adventitious root formation in tomato. The Plant Journal, v.61, n.1, p.3-15, 2010. https://doi.org/10.1111/j.1365-313X.2009.04027.x

PETRI, J.L.; HAWERROTH, F.J.; LEITE, G.B.; SEZERINO, A.A.; COUTO, M. Reguladores de crescimento para frutíferas de clima temperado. Florianópolis: Epagri, 2016. 141 p.

SANTOS, R.G.; SOUSA, I.M.D.; ALBUQUERQUE, C.C.D.; SILVA, K.M.B. Tipo de estaca e substrato na propagação vegetativa de Lippia gracilis Schauer. Arquivos do Instituto Biológico, v. 83, e0012014, 2016. https://doi.org/10.1590/1808-1657000012014
SHRESTHA, N.; WANG, Z.; SU, X.; XU, X.; LYU, L.; LIU, Y.; DIMITROV, D.; KENNEDY, J.D.; WANG, Q.; TANG, Z.; FENG, X. Global patterns of Rhododendron diversity: The role of evolutionary time and diversification rates. Global Ecology and Biogeography, v.27, n.8, p.913-924, 2018. https://doi.org/10.1111/geb.12750

STUEPP, C.A.; BITENCOURT, J.D.; WENDLING, I.; KOEHLER, H.S.; ZUFFELLATO-RIBAS, K.C. Indução de brotações epicórmicas por meio de anelamento e decepa em erva-mate. Ciência Florestal, v.26, n.3, p.1009-1022, 2016. https://doi.org/10.5902/1980509824230

SZYJEWICZ, E.; ROSNER, N.; KLIEWER, M.W. Ethephon ((2-Chloroethyl) phosphonic acid, Ethrel, CEPA) in viticulture - A review. American Journal of Enology and Viticulture, v.35, p.117-123, 1984.

VENDRUSCOLO, E.P.; MARTINS, A.P.B.; CAMPOS, L.F.C.; BRANDÃO, D.C.; NASCIMENTO, L.M.; SELEGUINI, A. Produção de mudas de batata-doce de baixo custo em diferentes substratos e níveis de enfolhamento de estacas. Journal of Neotropical Agriculture, v.4, n.2, p.102-110, 2017. https://doi. org/10.32404/rean.v4i2.1429

VÉRAS, M.L.M.; MENDONÇA, R.M.N.; RAMIRES, C.M.C.; SILVA, S.D.M.; PEREIRA, W.E. Effect of ethephon and indolebutyric acid on yellow mombin propagation via cutting. Pesquisa Agropecuária Tropical, v.47, n.4, p.416-423, 2017. https://doi.org/10.1590/1983$40632017 \mathrm{v} 4749515$

VÉRAS, M.L.M.; MENDONÇA, R.M.N.; SILVA, S.M.; FIGUEREDO, L.F.; ARAUJO, V.L.; PEREIRA, W.E.; MELO FILHO, J.S.; ANDRADE, R. Propagation of umbuzeiro (Spondias tuberosa Arr. Cam.), a native plant to Brazilian semi-arid regions, using ethephon and indolebutyric acid (IBA). Australian Journal of Crop Science, v.12, n.4, p.602-609, 2018. https://doi. org/10.21475/ajcs.18.12.04.pne888

VILLANOVA, J.; CANO, A.; ALBACETE, A.; LÓPEZ, A.; CANO, E.Á.; ACOSTA, M.; PÉREZ-PÉREZ, J.M. Multiple factors influence adventitious rooting in carnation (Dianthus caryophyllus L.) stem cuttings. Plant Growth Regulation, v.81, n.3, p.511-521, 2017. https://doi. org/10.1007/s10725-016-0228-1

WETZSTEIN, H.Y.; PORTER, J.A.; JANICK, J.; FERREIRA, J.F.; MUTUI, T.M. Selection and clonal propagation of high artemisinin genotypes of Artemisia апnиа. Frontiers in Plant Science, v.9, p.358, 2018. https://doi.org/10.3389/fpls.2018.00358

ZAYTSEVA, Y.G.; NOVIKOVA, T.I. Morpho-histological analysis of shoot regeneration and large-scale propagation of an endangered species Rhododendron mucronulatum Turcz. Siberian Journal of Forest Science, n.4, p.20-28, 2018. https://doi.org/10.15372/SJFS20180403 